EDUKACJA FILOZOFICZNA

VOL. 652018

WOJCIECH KOZYRA

Uniwersytet Kardynała Stefana Wyszyńskiego

\title{
KANT O WOLI I WOLNOŚCI
}

\section{Zarys problematyki}

Niniejszy artykuł stawia sobie za cel przedstawienie typologii pojęcia woli oraz stosowną do jej rozstrzygnięć „dystrybucję” wolności w Kantowskiej filozofii praktycznej. Interpretacja, którą przedstawię, prowadzi do pewnej kontrowersji, bynajmniej nieobcej badaczom etyki Kanta. Kontrowersja ta dotyczy tego, że ograniczając wolność do działań zapośredniczonych przez imperatyw kategoryczny, Kant czyni niemożliwym zachodzenie działań niemoralnych i wolnych, przez co ruguje także możliwość zaistnienia zła specyficznie moralnego, które odpowiadałoby moralnemu dobru. Na ten problem wskazał już Carl Christian Erhard Schmid w wydanej w 1790 roku (czyli dwa lata po drugiej Krytyce i pięć po Uzasadnieniu metafizyki moralności) książce Versuch einer Moralphilosophie, a punktem wyjścia dla swojej teorii wolności uczynił ów rzekomy niedostatek Kantowskiej teorii Fridrich Wilhelm Joseph von Schelling ${ }^{1}$, notabene znajdując się pod wpływem pracy Schmida²

\footnotetext{
1 Schelling przedstawił swoją filozofię wolności w opublikowanej w 1809 roku pracy Philosophische Untersuchungen über das Wesen der menschlichen Freiheit. Inną teorią wolności, również powstałą jako reakcja-remedium na etykę Kanta, była ta zaproponowana przez Carla Leonarda Reinholda w drugim tomie jego Briefe über die Kantische Philosophie, który ujrzał światło dzienne w 1792 roku. Henry Allison pisze, że w Metafizyce moralności Kant, krytykując koncepcję wolności jako libertas indifferentiae, odpowiada właśnie Reinholdowi. H. Allison, Kant's Theory of Freedom, Cambridge University Press, Cambridge 1990, s. 133. Allison informuje nas także, że Reinhold odpowiedział na Metafizykę zdziwieniem, spowodowanym tym, iż Kant odszedł od właściwego, według Reinholda, rozumienia wolności znanego z Religii w obrębie czystego rozu$m u$, powracając do swoich łatwo podważalnych poglądów na temat wolności z okresu krytycznego (tamże, s. 134).

2 M. Kosch, Freedom and Reason in Kant, Schelling and Kierkegaard, Calderon Press, Oxford 2006, s. 52.
} 
Kant odniósł się do zarzutów Schmida w opublikowanej w 1793 roku Religii w obrębie czystego rozumu ${ }^{3}$. Można postawić hipotezę, że wszędzie tam, gdzie Kant kładzie nacisk na to, iż zło moralne (Moralisch-Bösen) musi istnieć jako skutek wolności (inaczej bowiem zło to nie byłoby złem specyficznie moralnym), to nawiązuje on bezpośrednio do krytyki Schmida. Jednak jednoznaczna prezentacja wolności woli jako władzy do czynienia zarówno dobra, jak i zła jest w dziełach Kanta ograniczona do kart Religii, która w świetle jego filozofii praktycznej - wziętej in toto jawi się jako swego rodzaju anomalia ${ }^{4}$. Najlepszym tego dowodem jest opublikowana w 1797 roku Metafizyka moralności, w której Kant explicite odrzuca idee wolności jako libertas indifferentiae, tj. jako wspomnianą wyżej możliwość swobodnego wyboru spośród alternatywnych - tak moralnych, jak i niemoralnych - działań ${ }^{5}$. Myślę, że tę unikalność Religii można wyjaśnić - idąc za Heinzem Moshem Graupem - poprzez odwołanie do „tendencyjnego"6 charakteru tego dzieła, napisanego, jak sądzi Graupe, pod presją ówczesnego konserwatywnego układu polityczne-

\footnotetext{
3 Tamże.

4 Zauważa to również Michelle Kosch, tamże, s. 46.

5 Zob. I. Kant, Metafizyka moralności, tłum. E. Nowak, Wydawnictwo Naukowe PWN, Warszawa 2006, s. 36. W sprawie definicji libertas indifferentiae zob. tamże, s. 35. To, że pisma Kanta o etyce z okresu krytycznego nie wspierają woluntarystycznej koncepcji wolności zostanie wyłuszczone w dalszych częściach niniejszego artykułu. W tym momencie należy jednak zaznaczyć, że w swoich Reflexionen, pochodzących z lat 1764-1779 Kant prezentuje w kwestii wolności takie samo stanowisko jak w Metafizyce moralności. „Czy człowiek - pyta Kant w Reflexion 3865 - może być wyznaczony do czynienia zła moralnego z wolnego postanowienia [aus freiem Vorsatz]”? i odpowiada: „Nie!”. W Reflexion 1021 czytamy zaś, że „zdolność do działania wbrew obiektywnej determinacji [tj. determinacji przez prawo moralne] nie dowodzi wolności”. Również Reflexion 3867 stwierdza jednoznacznie: „Nikt nie poczytuje za wolność zdolności do pragnienia tego, co godne pogardy (złe) [...] wolność jest zdolnością do działania z pobudek rozumu". I. Kant, Texte zur Moralphilosophie aus Kants handschriftlichen Nachlass, w: Materialen zu Kants „Kritik der praktischen Vernunft”, R. Bittner \& K. Cramer (Hrsg.), Suhrkamp, Frankfurt am Main 1975, s. 33-46.

6 H. M. Graupe, Kant und das Judentum, „Zeitschrift für Religions- und Geistesgeschichte” 1961, Jg. 31, H. 4, s. 317; zob. też J. H. Zammito, The Genesis of Kant's Critique of Judgment, The University of Chicago Press, London, Chicago 1992, s. 241-243. Należy zastrzec, że artykuł Graupego dotyczy stosunku Kanta do religii żydowskiej, nie do kwestii wolnej woli, o tyle też nie wspiera mojej tezy bezpośrednio. Niemniej jednak owo „prawomyślne” rozumienie wolności, ku któremu Kant skierowuje się w Religii, bez wątpienia wpasowuje się w klimat ogólnego atawizmu religijnego konserwatyzmu z czasów Wilhelma II.
} 
go, który zapanował w Prusach po śmierci Fryderyka Wielkiego w 1786 roku? ${ }^{7}$. Warto też mieć na uwadze to, że od czasu rozgorzenia w latach osiemdziesiątych XVIII w. tzw. sporu o panteizm (Pantheismusstreit) Kantowi musiało zależeć na tym - zwłaszcza po śmierci Fryderyka - żeby zaznaczyć dystans dzielący go od spinozyzmu, który był w czasach Kanta utożsamiany z ateizmem i immoralizmem ${ }^{8}$. Częścią spinozyzmu zaś była właśnie negacja arbitralnej samorzutności woli.

Niezależnie od stopnia adekwatności tego wyjaśnienia faktem pozostaje - wziąwszy pod uwagę niewspółmierność tez o woli i wolności zawartych w Religii z treścią reszty etycznych pism Kanta - ryzykowność czynienia z tej pracy punktu odniesienia dla Kantowskiej teorii wolności, co uczynił choćby Henry Allison w Kant's Theory of Freedom - bez wątpienia najbardziej wpływowej współczesnej pracy na ten temat. Interpretacja Allisona, która definiuje wolność u Kanta jako zdolność do wcielania danej pobudki (moralnej lub nie) do maksymy działania (tzw. incorporation thesis), spotyka się z aprobatą ${ }^{9}$ głównie dlatego, jak sądzę, że czyni zadość naszym potocznym intuicjom ${ }^{10}$. Na ogół uważamy przecież, że

$7 \quad$ Tu można też odnotować, że publikacja Metafizyki moralności, w której Kant zaprzecza swoim tezom z Religii, zbiega się w czasie ze śmiercią Wilhelma II, konserwatywnego następcy Fryderyka.

8 Johann Gottfried Herder powiedział w 1787 roku, że ,wszystko, co niedorzeczne i bezbożne, było, i w pewnym stopniu wciąż jest, nazywane spinozyzmem”. Zob. B. Lord, Kant and Spinozism: Transcedental Idealism and Immanence from Jacobi to Deleuze, Palgrave Macmillian, London 2011, s. 7.

9 Zob. A. Reath, Kant's Theory of Moral Sensibility: Respect for the Moral Law and the Influence of Inclination, w: tegoż, Agency and Autonomy in Kant's Moral Theory, Oxford University Press, New York 2006, s. 12-19; Y. Yovel, Kant's Practical Reason as Will: Interest, Recognition, Judgment and Choice, „The Review of Metaphysics” 1998, Vol. 52, No. 2, s. 288; A. Wood, Kant's Ethical Thought, Cambridge University Press, Cambridge 1999, s. 51-53 J. Kloc-Konkołowicz, Rozum praktyczny $w$ filozofi Kanta $i$ Fichtego, Wydawnictwo Uniwersytetu Wrocławskiego, Wrocław 2007, s. 21-23. Również Johna Rawlsa wizja Kantowskiego podmiotu, jako władającego „wolą wybierającą" (elective will), przywodzi na myśl Allisonowską incorporation thesis. Rawls powołuje się wprawdzie w swoich wykładach z historii etyki na Kant's Theory of Freedom, ale nie w kontekście Kantowskiej teorii wolności, zob. J. Rawls, Kant, w: Lectures on the History of Philosophy, B. Hermann (ed.), Harvard University Press, Cambridge, London 2000, s. 177, 285. Autor $A$ Theory of Justice pisze wszakże, że ,dzięki wysiłkowi woli wybierającej [jesteśmy w stanie sprawdzić], czy możemy wcielić (incorporate) daną inklinację w [moralnie] dopuszczalną maksymę działania". Tamże, s. 178.

10 Trudno doprawdy dopatrzyć się innej przyczyny, dla której anty-Allisonowską interpretację 
jesteśmy wolni nie tylko w kontekście działań etycznie właściwych, jak również jesteśmy przeświadczeni, że zjawiska takie jak odpowiedzialność lub wina, w y maga ją zdolności do czynienia zła z wolne go wyboru. Na polu współczesnej metafizyki wolności spotykamy się jednak z teoriami, które w spójny, i dobrze uzasadniony sposób, c ałk o w i cie negują istnienie wolności ${ }^{11}$, nie rezerwując jej - jak według mnie czyni to Kant - dla działań będących skutkiem szacunku wobec praw moralnych. Sądzę, że sam fakt żywotności takich stanowisk we współczesnych debatach stricte metafizycznych, powinien być zachętą do potraktowania poniższego odczytania etyki Kanta z należytą powagą.

Niniejszy artykuł nie ma jednak bezpośrednio polemicznego charakteru, a jego głównym celem jest eksplikacja podziału pojęcia woli w Kantowskiej filozofii praktycznej, przy czym kwestia zapobieżenia nieintuicyjnym (czy za takie uważanym) konsekwencjom poniższych wywodów, jak również cała problematyka ontologicznych zobowiązań Kanta, są niejako wzięte w nawias, żeby nie zagrażały autonomii prezentowanej analizy. W toku rozważań podkreślę również znaczenie rzeczonej analizy dla relacji między wartością moralną i wolnością w filozofii Kanta, wskażę na ważne rozróżnienie między koniecznością moralną (obowiązkiem) i możliwością moralną (które pozwoli mi odróżnić wolę dobrą od woli czystej) oraz wykażę, że tam, gdzie Kant pisze o woli, rzecz dotyczy pewnej modalności woli, nie zaś woli simpliciter, której pojęciu, jak sądzę, trudno przypisać u Kanta jednoznaczną treść. Hermeneutyczny pożytek z takiego podejścia zaprezentuję, stosując skrupulatną dywersyfikację Kantowskiego pojęcia woli do naświetlenia wielorakich i konfundujących definicji woli simpliciter, z jakimi spotykamy się u tego filozofa. Najistotniejszym dla zrozumienia teorii moralnej Kanta wnioskiem pły-

wolności u Kanta, ujmującą etyczną motywację jako konstytutywną dla zachodzenia działań z wolności, oddala się ab initio, określając ją jako „dezinterpretację” (J. Kloc-Konkołowicz, dz. cyt., s. 27), ,absurdalny pogląd” (H. J. Paton, The Categorical Imperative: A Study in Kant's Moral Philosophy, The University of Chicago Press, Chicago 1948, s. 132) lub „błędne wrażenie” (Y. Yovel, dz. cyt., s. 281).

11 Mam tu na myśli przede wszystkim teorię przedstawioną w pracy Living Without Free Will autorstwa Dereka Perebooma, jak również prace Saula Smilansky’ego, w dużej mierze poświęcone dowiedzeniu etycznych korzyści płynących z przyjęcia tezy deterministycznej. 
nącym z mojej analizy pojęcia woli i wolności, którą przedstawiam poniżej, jest teza, że w filozofii moralnej Kanta wolna wola i wolność, choć ściśle ze sobą związane, nie są bynajmniej tym samym: posiadanie wolnej woli przez człowieka oznacza, twierdzę, właściwą mu możliw ość bycia wyznaczanym do działania przez prawo moralne ora z przez prawa przyrody. Z kolei wolność, jako rodzaj przyczynowości (Art von Kausalität), różny od przyczynowości naturalnej, określa wyłącznie a k t u a ln e działania, zachodzące ze względu na prawo moralne.

W artykule posłużę się całym korpusem krytycznym królewieckiego filozofa, uwzględniając Erste Einleitung in die Kritik der Urteilskraft (Pierwsze wprowadzenie do „Krytyki władzy sadzenia”). Poza tym odwołam się do Uzasadnienia metafizyki moralności i Metafizyki moralności, jak również do wykładów z etyki, które Kant wygłaszał w latach 17751880 .

\section{Wykaz pojęć}

Kant wyróżnia następujące modalności woli i pojęcia pokrewne. Mamy wolę (Wille), samowolę ${ }^{12}$ lub wolę arbitralną ${ }^{13}$ (Willkür), wolną wolę (freier Wille), czystą wolę (reiner Wille), dobrą wolę (guter Wille) oraz świętą wolę (heiliger Wille) - tymi pojęciami zajmę się w głównej części tekstu, zaczynając od tej ostatniej, a potem będę stopniowo kierować się „w dół" - do woli działającej w świecie zjawisk.

Pojęciami pozostającymi w ścisłym związku z wolą są pojęcia życia (Leben) oraz władzy pożądania (Begehrungsvermögen) - z jej wyższą (oberes) i niższą (unteres) odmianą. Te pojęcia poddam badaniu w osobnej części niniejszego artykułu.

Tłumaczenie Benedykta Bronsteina - tego tłumaczenia trzymam się w niniejszym artykule.

13 Tłumaczenie Ewy Nowak. 


\section{Analiza pojęcia woli}

Święta wola jest wolą, która nie może działać wbrew prawu moralne$\mathrm{mu}^{14}$. Prawo moralne nie jest dla niej preskrypcją ${ }^{15}$ (imperatywem), lecz stanowi deskrypcję jej relacji do innych świętych woli. W takim samym sensie prawa przyrody są deskrypcją związków kazualnych, w które wchodzą przedmioty materialne. A zatem: prawo moralne s a mo w sobie ma charakter opisowy, nie normatywny. Tylko rozumne istoty skończone (równie dobrze można by powiedzieć - uwydatniając dualność istoty ludzkiej u Kanta - pozaczasowe istoty czasowe), tj. ludzie - obarczeni całą inercją zmysłowości - mogą doświadczyć „,zniewolenia do czynu"16, czyli ujmować prawo moralne jako obowiązującą normę. Stąd wynika, że byt posiadający świętą wolę znajduje się ,poza dobrem i złem”, by wyrazić się po Nietzscheańsku. Staje się to natychmiast jasne, zaraz jak przypomnimy sobie, że wedle Kanta czyn posiada wartość moralną, tylko jeśli jest wykonany z poczucia obowiązku ${ }^{17}$. Posiadacz świętej woli nie może doznawać tego poczucia, toteż żadne z jego działań nie może posiadać wartości moralnej. Wartość moralna jest zatem wyrazem ludzkiej subiektywności. Co jest jednak, można zapytać, na gruncie Kanta obiektywne, tj. co człowiek podziela z bytem obdarzonym świętą wolą? Odpowiedź brzmi: wolność. Na przykład Bóg, wedle Kanta, jest nawet nie tyle wolny, ile doskonale wolny ${ }^{18}$. Wolność

\footnotetext{
14 Zob. I. Kant, Krytyka praktycznego rozumu, thum. B. Bronstein, Wydawnictwo Marek Derewiecki, Kęty 2015, s. 48.

15 W Krytyce praktycznego rozumu czytamy: „Dla istoty, w której wyłącznie nie sam rozum jest wyznacznikiem woli, prawidło to [prawo moralne] [...] jest i m p e r a ty w e m, tj. prawidłem, które jest znamionowane przez powinność". Tamże, s. 36; por. też tamże, s. 90. Natomiast w wykładach Kanta czytamy: „[...] w przypadku istoty najwyższej, praktyczna konieczność nie konstytuuje zobowiązania. Działania Boga są koniecznie moralne, ale nie zachodzą z obowiązku". I. Kant, Lectures on Ethics, tłum. L. Infeld, Harper \& Row, Michigan 1963, s. 15; zob. też tamże:16.

16 Por. I. Kant, Krytyka praktycznego rozumu, dz. cyt., s. 90.

17 Zob. I. Kant, Uzasadnienie metafizyki moralności, thum. M. Wartenberg, Wydawnictwo Marek Derewiecki, Kęty 201715, s. 24.

18 Zob. I. Kant, Lectures on Ethics, dz. cyt., s. 29-31. Wolność istoty ze świętą wolą podkreśla również Bernd Ludwig. Zauważa on też, że w związku z tym swobodna „wolność wyboru” (Wahlfreiheit) nie konstytuuje u Kanta właściwego, filozoficznego, pojęcia wolności i należy ją zaliczyć raczej do „psychologia empirica”. Zob. Ludwig B., Die Freiheit des Willens und die Freiheit zum Bösen: Inhaltliche Inversionen und terminologische Ausdifferenzierungen in Kants
} 
jest zatem tym, co „boskie” w człowieku, a nie dobro moralne, od którego to, co posiada świętą wolę, a zatem Bóg w szczególności, jest całkowicie odseparowane. Ten wywód zgadza się z Kantowskim ujęciem wolności jako rodzaju przyczynowości różnej od przyczynowości przyrodniczej i podległej innym niż przyczynowość przyrodnicza prawom (prawom moralnym lub prawom wolności ${ }^{19}$. Byt obdarzony świętą wolą nie zawiera w sobie niczego ze zmysłowości, co mogłoby spowodować zakłócenia owej nadzmysłowej - wolnej - przyczynowości wyznaczanej przez prawo moralne, i w tym sensie taki byt jest doskonale wolny ${ }^{20}$.

Człowiek natomiast nie jest doskonale wolny, dlatego że mo że popaść w niewolę (zmysłów). Dlatego jego wola, mówi Kant, może być co najwyżej czysta, ale nigdy święta. Tu, podobnie jak w całej filozofii Kanta, „czystość” oznacza brak empirycznego uwarunkowania. Wola ludzka jest czysta tylko wtedy, gdy jest aktualnie wyznaczana do działania przez prawo moralne ${ }^{21}$, tj. przez świadomość uniwersalizowalności danej maksymy. Zauważmy, że możemy posiadać czystą wolę, ni e działając z obowiązku. Jest to dość banalne spostrzeżenie: nie wszystkie przecież maksymy, które są moralnie możliwe, są również moralnie konieczne. Jeżeli tylko działania, które są powodowane przez obowiązkowy charakter danych maksym, posiadają wartość moralną, to te działania, które są

Moralphilosophie zwischen 1781 und 1797, w: Kants Rechtfertigung des Sittengesetzes in Grundlegung III: Deduktion oder Faktum?, H. Puls (Hrsg.), De Gruyter, Berlin 2014.

19 Zob. I. Kant, Krytyka praktycznego rozumu, thum. B. Bronstein, Wydawnictwo Marek Derewiecki, Kęty 2015, s. 61, 67, 76, 87. Również w Uzasadnieniu metafizyki moralności czytamy: „Ponieważ pojęcie przyczynowości zawiera w sobie pojęcie praw, według których przez coś, co nazywamy przyczyną, musi być urzeczywistnione coś innego, tj. skutek, więc wolność, jakkolwiek nie jest własnością woli [polegającą na działaniu - M. W.] według praw przyrody nie jest jednak w skutek tego czymś prawu zgoła nie podlegającym, lecz musi raczej być przyczynowością według niezmiennych praw [moralnych]". I. Kant, Uzasadnienie metafizyki moralności, dz. cyt., s. 62.

20 W Metafizyce moralności czytamy, że wolność nie może polegać na wybieraniu „przez rozumną istotę działań sprzecznych z jej własną (prawodawczą) rozumnością [...]. Wolność powiązana $\mathrm{z}$ wewnętrznym prawodawstwem rozumu - kontynuuje Kant - jest w istocie rzeczy jedynie rodzajem zdolności albo też mocy, wszelkie zaś odchylenie od niej - wyrazem niemocy". I. Kant, Metafizyka moralności, dz. cyt., s. 36. Stąd widać, że Bóg, jako istota nie mogąca doznawać żadnych zakłóceń w przynależnym mu z natury stanie zgodności z prawodawczym rozumem, jest wolny w sposób doskonały.

${ }^{21}$ Zob. I. Kant, Krytyka praktycznego rozumu, dz. cyt., s. 47, 67, 74. 
zwyczajnie dopuszczalne z punku widzenia prawa moralnego, mogą co prawda zachodzić $\mathrm{z}$ wolności, tj. być wykonywane niejako ze świadomości uniwersalizowalności odpowiadających im maksym ${ }^{22}$, ale jako nie-obowiązkowe nie mogą posiadać wartości moralnej. Nie ma w tym nic dziwnego: widzieliśmy już, że w przypadku bytu ze świętą wolą wartość moralna i wolność rozmijają się ze sobą, a nawet wzajemnie się wykluczają. Wracając do czystości woli: czysta wola, podaję definicję roboczą, jest wolą ludzką, która działa z wolności, przy czym wartość moralna jest jej cechą przypadłościową, nie zaś konieczną.

Taki pogląd pozwala na delineację dobrej woli. Dobra wola jest wprowadzona przez Kanta w Uzasadnieniu metafizyki moralności jako wola, która działa z poczucia obowiązku. Tak ją też tu rozumiem: dobra wola działa pod wpływem konieczności etycznej i jako taka jest odmianą czystej woli. Każda dobra wola jest czysta, natomiast nie każda czysta wola jest dobra, ponieważ nie każda czysta wola działa pod wpływem konieczności moralnej. Widzimy również, że świętość woli może być pojęta jako jej niezbywalna czystość, ale nie dobroć, ponieważ dobroć woli, jak już wiemy, może zaistnieć tylko w istotach uwarunkowanych zmysłowo.

Przechodzimy do wolnej woli. Wolna wola, pisze Kant, jest wolą, którą może wyznaczać prawo moralne ${ }^{23}$. Modalność „może” jest tu kluczowa. A raczej modalności, ponieważ należy dodać, że wolność woli jest podatnością zarówno na wpływ etyki, jak i przyrody ${ }^{24}$. Wolna

22 W Metafizyce moralności Kant wyróżnia (co czynił już wcześniej) pozytywny i negatywny aspekt wolności. Wolność negatywna oznacza niezależność od porządku przyrody, wolność pozytywna zaś odnosi się do aktywności niezapośredniczonej przez empirię. Pozytywny akt wolności, pisze Kant, ma miejsce wtedy, gdy „czysty rozum [jest] praktyczny [tj. aktywny przyczynowo, zob. Kant I., Uzasadnienie metafizyki moralności, dz. cyt., s. 64], co wszak zachodzić może tylko pod tym warunkiem, że maksyma przyświecająca danej osobie we wszelkich jej działaniach nadaje się do tego, żeby wystąpić jako prawo powszechne". I. Kant, Metafizyka moralności, dz. cyt., s. 17.

23 Zob. I. Kant, Krytyka praktycznego rozumu, dz. cyt., s. 45. W Krytyce czystego rozumu Kant podaję taką samą definicję, z tą różnicą, że używa terminu „freie Willkür”. Zob. Kant I., Krytyka czystego rozumu, t. II, tłum. R. Ingarden, Wydawnictwo Naukowe PWN, Warszawa 1957, s. 545 546.

24 W drugiej Krytyce czytamy, że „wolna wola nie jest sama przez się skierowana ku takim maksymom, które mogłyby umocnić same przez się przyrodę według powszechnych praw [...]; są to raczej osobiste skłonności, które tworzą wprawdzie całość 
wola jest określona poprzez te dwie własności modalne i nie odnosi się do aktualności. Kiedy wola ludzka podlega aktualnej determinacji jest bowiem zawsze albo wolą czystą, działającą z wolności, albo wolą uwarunkowaną zmysłowo, działającą nach der $\operatorname{Natur}^{25}$ (o czym niżej). Za takim rozumieniem wolnej woli przemawia to, że Kant uznaje, jak już powiedziałem, wolność za rodzaj przyczynowości, która zachodzi wyłącznie w obrębie prawa moralnego, stanowiącego jej konieczny wyznacznik. W związku z tym następująca konstatacja nabiera istotnego znaczenia: wolność woli i wolność jako rodzaj przyczynowości to, na gruncie etyki Kanta, dwie różne rzeczy ${ }^{26}$. Przypomnijmy sobie, wprowadzony już przeze mnie wcześniej, byt, który cechuje święta wola. Ów byt jest wolny, a nawet doskonale wolny, a przy tym nie posiada wolnej woli, tj. wolność nie jest dla niego możliw a (czyli zakłócana przez empirię) do osiągnięcia, lecz stanowi dla niego status quo, niedopuszczające odchyleń. Byt ten jest zatem doskonale wolny właśn i e dlatego, że nie posiada wolnej woli. Bardzo łatwo tu o nieporozumienie. Rozważmy np. twierdzenie Jakuba Kloca-Konkołowicza że „,[u Kanta] wolę [...] wolną czyni już sama możliw ość podlegania woli rozumnej"27. Sens, w jakim zgadzam się z tym twierdzeniem, jest osobliwy, mianowicie: sądzę, że jest prawdą, iż wola u Kanta jest wolna na mocy możli wo ś c i bycia determinowaną przez rozum, ale nie uważam żeby oznaczało to, iż owa wola działa z wolności (aus Freiheit) również wtedy, kiedy a k tu a ln i e nie ,podlega woli rozumnej [czyli prawu moralnemu]"28 (a tak właśnie

przyrody według patologicznych praw (fizycznych), lecz nie taką przyrodę, która byłaby możliwa dzięki naszej woli według czystych praktycznych praw". I. Kant, Krytyka praktycznego rozumu, dz. cyt., s. 58.

25 W Krytyce czystego rozumu Kant pisze, że istnieją tylko dwa możliwe do pojęcia rodzaje przyczynowości: wolność i przyroda, a każde zdarzenie należy, albo do jednego, albo drugiego porządku kauzalnego. Por. I. Kant, Krytyka czystego rozumu, dz. cyt., s. 276. Przyczynowość j a k o ta ka zaś posiada, według Kanta, nomologiczno-necessarystyczny charakter. Zob. I. Kant, Krytyka czystego rozumu, dz. cyt., s. 292. Stąd widać, że filozof z Królewca postuluje istnienie dwóch determinizmów kauzalnych: determinizmu przyrody oraz, jakkolwiek paradoksalnie by to brzmiało, determinizmu wolności.

26 Kant zdaje się wskazywać na podobne rozróżnienie, gdy w wykładach zwraca uwagę na różnicę między „możnością wolności” i „stanem wolności”. I. Kant, Lectures on Ethics, dz. cyt., s. 30.

27 J. Kloc-Konkołowicz, dz. cyt., s. 86.

28 Podobną myśl wyraził Hermann Cohen w pracy Kants Begründung der Ethik. To, co ja 
zdaje się sądzić Kloc-Konkołowicz, na co wskazuje zbieżność jego poglądów na wolność u Kanta z poglądami Allisona). Z wolności, tj. na mocy przyczynowości, której prawem jest prawo moralne, działa tylko święta, czysta albo dobra wola.

Teraz czeka nas najważniejsze zadanie: określić pojęcie woli u Kanta w odniesieniu do porządku przyrody.

Wiemy, że wolna wola, kiedy jest aktualnie wyznaczana do działania, jest wyznaczana do działania albo przez moralne prawodawstwo rozumu, albo przez porządek przyrody. A to oznacza, że zawsze, gdy wolę determinuje do działania coś co n i e jest prawem moralnym, to determinuje ją coś co jest przyrodą. Zobrazujmy to sobie na następujących przykładach. Przedstawmy sobie wolę człowieka, gdy ten chce A) kupić sobie parę butów, ale ostatecznie przeznaczone na nie pieniądze oddaje na cele charytatywne, ponieważ chce ulżyć potrzebującym, B) zjeść coś tłustego, ale powstrzymuje się od tego, ponieważ chce się odchudzić, i C) zjeść coś tłustego i odruchowo zamawia pizzę. Zapytajmy teraz: co determinuje w tych przykładach ludzką wolę na gruncie Kantowskiej filozofii? Najogólniejsza odpowiedz brzmi: przyroda. We wszystkich tych przypadkach, w których występuje działanie mniej lub bardziej instynktowne (patrz poniższe uwagi o deliberacji), aczkolwiek w żadnym nie ma miejsca determinacja zapośredniczona przez moralne principia, wolna wola ludzka aktualizuje się jako część przyrody, czyli jako samowola. Kant wielokrotnie podkreśla, że ludzka samowola należy do porządku natury zmysłowej29. Samowola jest według tego filozofa, podaję roboczą definicję, właściwą

nazywam dwoma własnościami modalnymi wolnej woli, Cohen określał jako „Willkür in bonam partem” oraz „Willkür in malam partem”, z których pierwsza odnosi się dyspozycji moralnej, zawartej w woli człowieka, a druga wskazuje na jej dyspozycje do poddawania się wpływom zmysłowości. Przy tym Cohen podkreślał, że te dwa aspekty woli są, wedle Kanta, niewystarczające do „zagwarantowania” (verbürgt) wolności. H. Cohen, Kants Begründung der Ethik, w: tegoż, Hermann Cohen: Werke, Bd. II, Georg Olms, Hildesheim-Zürich-NY 2001, s. 239-240.

29 Np. w Krytyce czystego rozumu czytamy: „Człowiek jest sam zjawiskiem, jego własna wola [tak Ingarden thumaczy termin „Willkür”] posiada charakter empiryczny, który jest empiryczną przyczyną wszystkich jego czynności" (I. Kant, Krytyka czystego rozumu, dz. cyt., s. 295) oraz: „Wola własna jest jedynie wolą zwierzęcą (arbitrium brutum), która może być określana tylko przez popędy zmysłowe, tj. patologicznie" (tamże, s. 545-546). 
człowiekowi zdolnością do urzeczywistniania przedmiotów przedstawień, które ma na celu osiągnięcie przez człowieka stanu szczęśliwości ${ }^{30}$.

Taka koncepcja samowoli czyni jasnym to, że i celowość ostatecznie zalicza się u Kanta do porządku natury zmysłowej ${ }^{31}$. Celowość Kant definiuje jako „przyczynowość pojęcia w odniesieniu do jego przedmiotu”32. Ten przedmiot jest właśnie stanem rzeczy, którego „pojęcie” (przedstawienie) może w sposób patologiczny (zmysłowy) wyznaczać do działania wolną wolę qua samowolę. Z kolei, gdy samowola jest wyznaczana do działania przez treść pojęcia, to - koniec końców - kieruje nią pragnienie szczęśliwości, czyli przyjemności towarzyszącej egzemplifikacji tej treści. W Erste Einleitung in die Kritik der Urteilskraft Kant przedstawia ludzkie dążenie do szczęścia jako sposób, w który przyroda - tu jako homo phenomenon (konkretnie: homo sapiens) - dąży do osiągnięcia równowagi sił. Ten zaś sposób - pisze Kant - nie różni się co do rodzaju od przemian, jakim podlegają ciała czysto materialne. W Erste Einleitung, Kant zapewnia nas, że wszystkie zasady praktyczne, wypływające z ludzkiej samowoli [alle praktischen Sätze [...] von der Willkür als ursache ableiten [...]], nie stanowią właściwego przedmiotu (Inhalt) filozofii praktycznej, który jest konstytuowany dopiero przez wolność jako przyczynowość nadzmysłową i odpowiadające jej prawa ${ }^{33}$. Zauważmy, że ilustrację ta-

\footnotetext{
30 W Krytyce praktycznego rozumu czytamy, że „,wszelka materia prawideł praktycznych [czyli przedmiotów wyznaczających do działania samowolę] [...] grupuje się wokoło zasady własnej szczęśliwości”. I. Kant, Krytyka praktycznego rozumu, dz. cyt., s. 50. Kant rozumie szczęśliwość (Glückseligkeit) jako przyjemność płynącą z zaspokojenia potrzeb zmysłowych. I. Kant, Krytyka czystego rozumu, dz. cyt., s. 549. Jednak według Kanta pojęcie potrzeby zmysłowej ma szeroki zakres i dotyczy nie tylko tego, co język polski określa jako „potrzeby ciała”, ale odnosi się również do „potrzeb ducha”. Zob. Kanta krytyka demarkacji wyższej i niższej władzy pożądania według kryterium pojęciowości w I. Kant, Krytyka praktycznego rozumu, dz. cyt., s. 38-41. Tak ujęta ludzka szczęśliwość jest, wedle Kanta, koniecznym i nigdy nieustającym „hipotetycznoasertorycznym" imperatywem każdego człowieka, o ile rozpatruje się go jako część natury (tj. jako zjawisko). Por. I. Kant, Uzasadnienie metafizyki moralności, dz. cyt. s. 33.

31 Teoria kauzalna Kanta jest w tym punkcie zbieżna z teorią Spinozy. Zarówno Kant, jak i Spinoza uznawali prymat modelu wyjaśniania odwołującego się do przyczyn sprawczych, a celowość zrzucali na karb ludzkiej subiektywności. To podobieństwo wskazała i omówiła Beth Lord, dz. cyt. s. 93-97.

32 I. Kant, Krytyka władzy sadzenia, dz. cyt., s. 89.

33 Zob. I. Kant, Erste Einleitung in die Kritik der Urteilskraft, w: tegoż, Immanuel Kants Werke, Bd. V, Ernst Cassirer (Hrsg.), B. Cassirer, Berlin 1914, s. 180-187.
} 
kich zasad znajdujemy w przytoczonych powyżej przykładach $A$ i $B$. Co jednak ważne: ponieważ przykład $C$ nie uwzględnia procesu deliberacji, to Kant nie obawia się, że zostanie on wzięty za właściwy przypadek wolności. To właśnie ów proces sugeruje inny rodzaj przyczynowości niż natura ${ }^{34}$. Unaocznieniu tego właśnie, że jest to pozór i że etycznie neutralna (a zatem, by tak rzec, „hedonistycznie pozytywna”) deliberacja jest modalnością przyczynowości zmysłowej, Kant poświęcił znaczną część Erste Einleitung ${ }^{35}$. W tym tekście Kant przestrzega również przed analizowaniem - „należących do przyrody”36 - samowolnych działań (willkürliche Handlungen), w kategoriach wolności, ponieważ prowadzi to, według niego, do wadliwej metodologii, która powoduje krzyżowanie się tych z konieczności heterogenicznych domen naukowych. To ma na myśli Kant, gdy twierdzi, że w żadnym wypadku nie może być mowy o możliwości ufundowania ,praktycznej psychologii”37.

Również jeżeli uzmysłowimy sobie, że etyka jest dla Kanta właśnie $\mathrm{nauka} \mathrm{a}^{38}$, to łatwo przyjdzie nam zrozumienie tego, że jej przedmiotem nie jest wola działająca według przedstawienia c elów. Naukowa etyka, o ile jest naukowa, akceptuje wyłącznie paradygmat wyjaśniania w kategoriach przyczyn sprawczych. Dla etyki jako takiej człowiek jest czystą wolą, której działanie opisuje prawo moralne ${ }^{39}$. Wola ta jest

\footnotetext{
34 To, że procesy kauzalne związane z ,przemyślanymi decyzjami” (überlegte Entscheidungen) wpisują się, według Kanta, w porządek przyrody podkreśla również Bernd Ludwig, dz. cyt.

35 W drugiej Krytyce również spotykamy się tym poglądem Kanta. W tym dziele Kant odróżnia przyczynowość czysto materialną od przyczynowości psychologicznej, tj. takiej, która „uskutecznia działania dzięki przedstawieniom, a nie dzięki ruchom cielesnym”, oraz dodaje, że to rozróżnienie zachodzi w obrębie przyrody i może stanowić jedynie o wolności „porównawczej” bądź ,psychologicznej”. I. Kant, Krytyka praktycznego rozumu, dz. cyt., s. 102-103.

36 Zob. I. Kant, Erste Einleitung in die Kritik der Urteilskraft, dz. cyt., s. 180.

37 Zob. tamże: 182. Także w przedmowie do drugiej Krytyki Kant „zauważa ze zdziwieniem”, że „wielu ludzi, rozpatrując to pojęcie [wolność] tylko pod psychologicznym względem, chwali się, jakoby je bardzo dobrze rozumiało [...]". I. Kant, Krytyka praktycznego rozumu, dz. cyt., s. 23.

38 Kant wyróżnia (obok matematyki) trzy nauki: etykę, fizykę i logikę. Dwie pierwsze posiadają właściwe sobie domeny przedmiotowe, natomiast logika dotyczy samej tylko formy myślenia. Zob. I. Kant, Uzasadnienie metafizyki moralności, dz. cyt., s. 5.

39 Tak też etykę Kanta postrzegał Hermann Cohen, pisze on: „[...] w ostatecznym rozrachunku człowiek jest [dla etyki Kanta] jedynie punktem odniesienia, tak jak dla nauk jest on jedynie przypadkiem właściwych im praw”. H. Cohen, Die Religion der Vernunft aus den Quellen des
} 
p o py chana do działania przez świadomość uniwersalizowalności odpowiadającej mu maksymy. Przedstawienie konsekwencji tego działania, tj. celów, które mogłyby by być determinantami s a mowoli, nie może odgrywać roli przyczynowej w etiologii owego działania, o ile ma ono być rozpatrywane jako przedmiot etyki.

\section{Kantowska typologia woli a Kantowskie określenia woli}

Nie sposób odpowiedzieć wprost na pytanie: „Czym u Kanta jest wola simpliciter?". Żeby zatem uniknąć rozczarowań prymitywnego indukcjonizmu, któremu pisane jest zagubienie się w różnorakich definicjach woli simpliciter w pismach Kanta, należy podchodzić do nich z wyżej wypracowaną aparaturą pojęciową.

Poniżej przedstawię i odpowiednio sklasyfikuję definicje woli, które Kant zawarł w Uzasadnieniu metafizyki moralności. Tę typologizację można, rzecz jasna, zastosować również do innych kwestii obecnych w jego filozofii (proponuję czytelnikowi odnieść ją np. do wprowadzonych przez Kanta w Uzasadnieniu, i rozwiniętych w drugiej Krytyce, pojęć autonomii i heteronomii woli).

W Uzasadnieniu czytamy, że wola to A) ,władza działania według przedstawienia praw, tj. według zasad [Prinzipien]”40, B) „rozum praktyczny" $\left.{ }^{41}, C\right)$,władza wybierania tylk o te go, co rozum poznaje niezależnie od skłonności jako praktycznie konieczne [podkr. - I. K.]"42, D) ,zdolność nakłaniania się do czynu według przedstawienia pewnych praw”43, E) „rodzaj przyczynowości istot żyjących, o ile są rozumne, [podczas gdy] wolność [jest] własnością tej przyczynowości, dzięki której może ona [tj. istota rozumna] działać niezależnie od obcych skłaniających ją przyczyn”44. I jeszcze F) „Istota rozumna zalicza się jako inteligencja

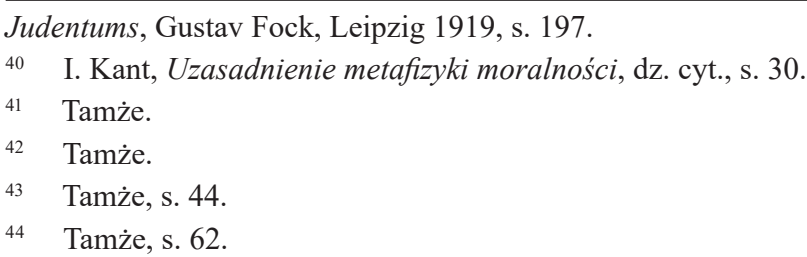


do świata intelektu i tylko jako do niego należąca przyczyna sprawcza nazywa ona swą przyczynowość wolą"45.

Ad A. W przytoczonym cytacie głównym problemem interpretacyjnym jest ustalenie odniesienia terminu „Prinzipien”. Jeżeli uznamy, że odnosi się on do tego, co Kant nazywa „materiale Prinzipien”46, to tym samym stwierdzimy, że w A Kant uznaje za koekstensywne pojęcia, które gdzie indziej niejednokrotnie rozróżnia. Na przykład w drugiej Krytyce czytamy, że tylko ,prawa” (Gesetze) wyznaczają kierunek „,woli jako woli”47 natomiast ,praktyczne zasady” (w tym przypadku Kant używa terminu ,praktische Vorschriften”, który jednak oznacza to samo co praktyczne „materiale Prinzipien”, czyli amoralne reguły działania ${ }^{48}$ ) nie wyznaczają woli „wprost jako woli, lecz tylko ze względu na pożądany skutek" ${ }^{49}$. Jeżeli natomiast obierzemy za przedmiot odniesienia terminu „Prinzipien” z cytatu A a priori praktische Prinzipien ${ }^{50}$, to wtedy uzyskamy spójny wywód. Jednakże w obliczu naszych uprzednich rozważań nie powinna nam spędzać snu z powiek kwestia tego, co Kant ma na myśli, pisząc ,,[...] praw [Gesetze], tj. według zasad [Prinzipien]". Liczy się to, co mo że on mieć na myśli. A więc stosowna „mapa możliwości” przedstawia się następująco: jeżeli w A mowa jest o woli, którą determinują tylko prawa jako aprioryczno-praktyczne pryncypia, to jest to jest to czysta wola, jeżeli natomiast chodzi o wolę, którą determinują tylko zasady jako aposterioryczno-praktyczne Vorschriften lub takież materiale Prinzipien, to jest to samowola. Jeżeli zaś mowa jest o woli, którą mogą determinować prawa $1 \mathrm{u}$ b zasady (w powyższym znaczeniu tych pojęć), to rzecz dotyczy wolnej woli.

\footnotetext{
$45 \quad$ Tamże, s. 69.

46 Zob. I. Kant, Krytyka praktycznego rozumu, dz. cyt., s. 38.

47 Tamże, s. 36.

48 W drugiej Krytyce Kant zdaje się używać terminów „Vorschriften” oraz „Prinzipien” zamiennie; czytamy tam np., że ,wszystkie zasady praktyczne [tym razem w oryginale znajdujemy „praktische Prinzipien”, a nie - jak wyżej - „Vorschriften”], które w swym założeniu przyjmują przedmiot (materię) władzy pożądania jako wyznacznik woli, są empiryczne i nie mogą stanowić praw praktycznych [praktischen Gesetze]". Tamże, s. 37.

49 Tamże, s. 36.

50 Zob. tamże, s. 48.
} 
Ad B. To, co jest dla nas ważne w tożsamości woli z rozumem praktycznym, to to, że z prawodawczym rozumem praktycznym tożsama może być tylko wola ujęta niezależnie od zmysłowości, tj. czysta, lub dobra wola (o ile mowa jest o człowieku), ponieważ rozum praktyczny jest u Kanta bytem nadzmysłowym ex definitione.

Ad C. Tu chodzi o wolę determinowaną do działania przez konieczność moralną, czyli o dobrą wolę.

Ad D. Podobnie jak w przypadku A. Można jednak, jak sądzę, rozsądnie przypuszczać, że konkretyzujące słówko „pewnych” wskazuje na prawa właściwe „woli jako woli”, tj. prawa moralne.

Ad E. Zgodnie $\mathrm{z}$ omawianą już przeze mnie w niniejszym artykule Kantowską zasadą tertium non datur, a odniesioną do przyczynowości zmysłowej i nadzmysłowej, wiemy, że jeżeli wolę coś determinuje do działania - a nie jest to zmysłowość (przyroda) - to jest to moralne prawodawstwo. To, że to właśnie etyka jest dla woli „nieobcą”, lecz właściwą jej determinantą, można wnosić już choćby z tego, że według Kanta prawo moralne wyznacza do działania wolę jak o taką ${ }^{51}$. Wolność woli oznacza więc dla woli mo żli w o ść - tak jak w przypadku E - poddania się prawu moralnemu. Tu można też spokojnie dopowiedzieć, że zmysłowość jest z kolei tą własnością woli, przez którą mo że ona działać (czy raczej oddziaływać) zale żnie od „obcych” jej przyczyn jako samowola. Myślę więc, że można rozsądnie twierdzić, że w E chodzi o wolną wolę.

Ad. F. Tu chodzi o czystą wolę, tj. działającą wedle prawa moralnego przyczynę s prawczą.

\section{Władza pożądania i życie}

W Krytyce praktycznego rozumu Kant definiuje pojęcie życia przez pojęcie władzy pożądania: „Życie - pisze - to cechująca istotę zdolność postępowania według praw władzy pożądania"52. A zaraz potem podaje następującą definicję tejże władzy: „Władza pożądania jest zdolnością

\footnotetext{
51 Widać to również po tym, że Kant łączy wolę skłanianą przez prawo z „właściwą jaźnią” (eigentlich selbst) człowieka. Zob. I. Kant, Uzasadnienie metafizyki moralności, dz. cyt., s. 76.

52 I. Kant, Krytyka praktycznego rozumu, dz. cyt., s. 24.
} 
istoty, dzięki której staje się ona poprzez swe przedstawienia przyczyną rzeczywistości przedmiotów tych przedstawień" ${ }^{53}$. Kant zaznacza przy tym (o czym już wcześniej wspomniałem), że urzeczywistnianie treści pojęciowych (przedmiotów przedstawień) jest z konieczności podporządkowane, by użyć Freudowskiego żargonu, „zasadzie przyjemności”, w konsekwencji czego wpisuje się w porządek przyrody, nie zaś w nadzmysłowy porządek wolności.

Widzimy zatem, że życie nabiera u Kanta zgoła fizycznego (w szerokim sensie) charakteru ${ }^{54}$. Nie dziwi więc, że królewiecki filozof określa czasem życie ludzkie per se jako nie przedstawiające żadnej szczególnej wartości ${ }^{55}$.

Wracając teraz do przedstawionej przez Kanta definicji życia, chciałbym zwrócić uwagę, że sprawia ona wrażenie kolistej. Władza pożądania jest zdolnością do działania kierowanego przez pragnienia i przekonania, tj. życiem, które jest przecież zdolnością do ,postępowania” (handeln) według ,praw władzy pożądania”, tj. do określania własnej aktywności, powodując się ekonomią pragnień i przekonań. W Metafizyce moralności Kant podaje definicję życia, nie uwzględniając już władzy pożądania; czytamy tam, że „[życie jest] przyrodzoną niektórym istotom zdolnością do działań zgodnych z wytwarzanymi przez nie przedstawieniami" 56 . Jak widać, pojęcie życia nabiera tu cechy, którą Kant w drugiej Krytyce przypisał pojęciu władzy pożądania, przez którą to pierwsze pojęcie było tam zdefiniowane. W związku z powyższym uważam, że można bezpiecznie traktować życie i władzę pożądania jako pojęcia równozakresowe. Jest również, jak sądzę, klarowne, że w tę parę pojęć wpasowuje się i pojęcie

\footnotetext{
$53 \quad$ Tamże.

54 Jak wiadomo, Kant był stanowczym oponentem hylozoizmu (J. H. Zammito, dz. cyt., s. 189). Pisząc zatem, że życie zostaje przez Kanta zaliczone do przyrody, a więc ipso facto do domeny nauk ścisłych, nie chcę przez to, rzecz jasna, powiedzieć, że postulował on istnienie ożywionej materii jako takiej.

55 Zob. I. Kant, Krytyka praktycznego rozumu, dz. cyt., s. 95; zob. też Kant I., Metafizyka moralności, dz. cyt., s. 179.

56 Tamże, s. 13.
} 
samowoli, która też przecież odnosi się do zmysłowej zdolności przyczynowej istoty ludzkiej ${ }^{57}$.

Została nam do poruszenia jeszcze kwestia wyższej i niższej władzy pożądania. Tu ograniczę się do następującej uwagi: władza pożądania simpliciter staje się niższa dopiero po skontrastowaniu ją z wyższą władzą pożądania, która jest tożsama z czystą wolą. Czytamy w Krytyce praktycznego rozumu, że ,zasada własnej szczęśliwości [...] nie zawiera żadnych wyznaczników woli [innych] niż te, które odpowiadają niższej władzy pożądania"58. Niższa władza pożądania jest zatem zmysłową konstytuantą (wolnej) woli i jako taka jest tym samym w filozofii Kanta co władza pożądania simpiciter. Uznanie tej władzy za „niższą” nabiera sensu dopiero wtedy, gdy mamy ,wyższą” władzę pożądania, którą Kant utożsamia z czystym rozumem praktycznym ${ }^{59}$, a więc ipso facto z czystą wolą.

\section{Zakończenie}

Typologia Kantowskiego pojęcia woli, którą przedstawiłem powyższej, stanowi narzędzie do orientowania się w etycznej myśli Kanta. Co jednak ważniejsze, wykazuje ona zdecydowany antylibertarianizm Kantowskiej metafizyki wolności oraz naświetla kluczową różnicę, jaka zachodzi u Kanta między posiadaniem wolnej woli a działaniem z wolności. Dokładne określenie różnych rodzajów woli w filozofii autora Krytyk pozwoliło mi też na wyłuszczenie interesujących, jak mniemam, stosunków, w jakich pozostają one względem wartości moralnej, konieczności moralnej i takiejże możliwości.

Powyższa interpretacja Kanta przedstawia spore wyzwanie dla naszego potocznego obrazu świata. Fakt ten jednak, sam w sobie, nie stanowi racji przeciwko niej. Jak już zaznaczyłem na początku tego artykułu, an-

\footnotetext{
57 We wstępie do trzeciej Krytyki Kant charakteryzuje władzę pożądania w ten sam sposób, w jaki określa samowolę w Krytyce czystego rozumu i w Erste Einleitung, tj. jako,,jedną z licznych przyczyn naturalnych w świecie, mianowicie taką, która działa na podstawie pojęć". I. Kant, Krytyka władzy sądzenia, dz. cyt., s. 13.

58 Zob. I. Kant, Krytyka praktycznego rozumu, dz. cyt., s. 40.

59 Zob. tamże.
} 
tylibertariańska metafizyka wolności ${ }^{60}$, która godzi w zdroworozsądkowe status quo, posiada solidną reprezentację we współczesnej debacie. Uważam też, że ów, wspomniany już przez mnie powyżej, specyficzny ,,determinizm wolności”, z którym spotykamy się u Kanta, może stanowić sam w sobie interesującą propozycję dla niezależnego namysłu filozoficznego. Wystarczy powiedzieć, że na gruncie takiego poglądu to, co się często uważa za konieczny warunek wolności działania, czyli możliwość zrobienia czegoś innego niż czynu faktycznie dokonanego, nie tyle nawet nie stanowiłoby warunku sine qua non wolności (czego dowodzi Harry Frankfurt w swoim słynnym eseju Alternate Possibilities and Moral Responsibility), ile wręcz świadczyłoby - w przypadku możliwości podjęcia działania sprzecznego z obowiązkiem - niejako o jej niezupełności.

W zawiązku z powyższym pragnę również wyrazić swoje poparcie wobec artykułu-apelu Yitzhaka Melameda Charitable Interprteations and the Political Domestication of Spinoza, or, Benedict in the Land of Secular Imagination, w którym autor nawołuje do zaprzestania nadużywania tzw. zasady życzliwości (principle of charity) w procesie interpretacji historycznych tekstów filozoficznych ${ }^{61}$. Jak zauważa Melamed, ,życzliwi” interpretatorzy często idą za daleko w bronieniu autorytetów filozoficznych z przeszłości przed przypisywaniem im, ich zdaniem, ,absurdalnych” poglądów i stosownie do tego przejawiają tendencję do imputowania im tez, które oni sami uznają za godne uwagi. Przez to zaś - co również podkreśla Melamed - znacznie zmniejszają prawdopodobieństwo skonfrontowania

\footnotetext{
60 Ponieważ termin „libertarianizm” przywarł do kontekstu teorii politycznej, chciałbym zastrzec, że używam go - tak jak to również jest w zwyczaju - w znaczeniu stricte metafizycznym.

${ }_{61} \quad$ Wydaje mi się, że przykład takiego postępowania znajdujemy w artykule Willkür und Wille bei Kant Pirmina Stekeler-Weithofera. Bowiem autor ten, niedhugo po tym jak explicite zadeklarował posługiwanie się w interpretacji Kanta zasadą życzliwości, pisze: „Należy przyznać, że terminologia Kanta dość pochopnie przeciwstawia prawom natury 'prawa wolności', tj. prawa 'rozumu praktycznego', ujęte jako prawa m o r a l n e, podczas gdy również techniczno-praktyczne [prawa] a wraz z nimi, odnoszące się do określania celów, imperatywy 'hipotetyczne’ [tj. reguły amoralne] [...] muszą stanowić istotną część całościowej analizy filozoficznej dotyczącej wolnych działań”.P. Stekeler-Weithofer, Willkür und Wille bei Kant, „Kant-Studien” 1990, Jg. 81, H. 3, s. 309. O ile dobrze go rozumiem, Stekeler-Weithofer ma tu na myśli to, że uznanie zwyczajnych procesów decyzyjnych za przejaw wolności, jest zjawiskiem, które teoria takich procesów „musi” zachować. I w rzeczy samej, takie przeświadczenie jest naszym „chlebem powszednim”, niemniej jednak, co starałem się wykazać powyżej, etyka Kanta je kontestuje.
} 
się z in n y m, i dlatego odpowiednio stymulującym, podejściem do problemów filozoficznych ${ }^{62}$.

\section{Bibliografia}

Allison H., Kant's Theory of Freedom, Cambridge University Press, Cambridge 1990.

https://doi.org/10.1093/0199289115.001.0001

Cohen H., Die Religion der Vernunft aus den Quellen des Judentums, Gustav Fock, Leipzig 1919.

Cohen H., Kants Begründung der Ethik, w: tegoż, Hermann Cohen: Werke, Bd. II, Georg Olms, Hildesheim-Zürich-NY 2001.

Graupe H. M., Kant und das Judentum, „Zeitschrift für Religions- und Geistesgeschichte" 1961, Jg. 31, H. 4, s. 308-333.

Kant I., Erste Einleitung in die Kritik der Urteilskraft, w: tegoż, Immanuel Kants Werke, Bd. V, Ernst Cassirer (Hrsg.), B. Cassirer, Berlin 1914, s. 179-231.

Kant I., Krytyka czystego rozumu, t. II, thum. R. Ingarden, Wydawnictwo Naukowe PWN, Warszawa 1957.

Kant I., Krytyka praktycznego rozumu, tłum. B. Bronstein, Wydawnictwo Marek Derewiecki, Kęty 2015.

Kant I., Krytyka władzy sądzenia, tłum. J. Gałecki, Wydawnictwo Naukowe PWN, Warszawa 1986.

Kant I., Lectures on Ethics, tłum. L. Infeld, Harper \& Row, Michigan 1963.

Kant I., Metafizyka moralności, tłum. E. Nowak, Wydawnictwo Naukowe PWN, Warszawa 2006.

Kant I., Uzasadnienie metafizyki moralności, tłum. M. Wartenberg, Wydawnictwo Marek Derewiecki, Kęty 2017.

62 Y. Melamed, Charitable Interpretations and the Political Domestication of Spinoza, or, Benedict in the Land of the Secular Imagination, w: The Methodology of the History of Philosophy, M. Laerke \& E. Schilsser (eds.), Oxford University Press, Oxford 2013, s. 258-277. 
Kant I., Texte zur Moralphilosophie aus Kants handschriftlichen Nachlass, w: Materialen zu Kants ,Kritik der praktischen Vernunft”, R. Bittner \& K. Cramer (Hrsg.), Suhrkamp, Frankfurt am Main 1975, s. 33-136. Kloc-Konkołowicz J., Rozum praktyczny w filozofii Kanta i Fichtego, Wydawnictwo Uniwersytetu Wrocławskiego, Wrocław 2007.

Kosch M., Freedom and Reason in Kant, Schelling and Kierkegaard, Calderon Press, Oxford 2006.

https://doi.org/10.1093/0199289115.001.0001

Lord B., Kant and Spinozism: Transcedental Idealism and Immanence from Jacobi to Deleuze, Palgrave Macmillian, London 2011. https://doi.org/10.1057/9780230297722

Ludwig B., Die Freiheit des Willens und die Freiheit zum Bösen: Inhaltliche Inversionen und terminologische Ausdifferenzierungen in Kants Moralphilosophie zwischen 1781 und 1797, w: Kants Rechtfertigung des Sittengesetzes in Grundlegung III: Deduktion oder Faktum?, H. Puls (Hrsg.), De Gruyter, Berlin 2014, s. 227-268.

Melamed Y., Charitable Interpretations and the Political Domestication of Spinoza, or, Benedict in the Land of the Secular Imagination, $\mathrm{w}$ : The Methodology of the History of Philosophy, M. Laerke \& E. Schilsser (eds.), Oxford University Press, Oxford 2013, s. 258-277.

Paton H. J., The Categorical Imperative: A Study in Kant's Moral Philosophy, The University of Chicago Press, Chicago 1948.

Rawls J., Kant, w: Lectures on the History of Philosophy, B. Hermann (ed.), Harvard University Press, Cambridge, London 2000, s. 143325.

Reath A., Kant's Theory of Moral Sensibility: Respect for the Moral Law and the Influence of Inclination, w: tegoż, Agency and Autonomy in Kant's Moral Theory, Oxford University Press, New York 2006, s. 8-33.

Stekeler-Weithofer P., Willkür und Wille bei Kant, „Kant-Studien” 1990, Jg. 81, H. 3, s. 304-320.

Wood A., Kant's Ethical Thought, Cambridge University Press, Cambridge 1999.

https://doi.org/10.1017/CBO9781139173254 
Yovel Y., Kant's Practical Reason as Will: Interest, Recognition, Judgment and Choice, „The Review of Metaphysics” 1998, Vol. 52, No. 2 , s. 267-294.

Zammito J. H., The Genesis of Kant's Critique of Judgment, The University of Chicago Press, London, Chicago 1992.

\section{Summary}

This article presents Kant's typology of the concept of will. The following Kantian concepts fall under scrutiny: free will, good will, power of choice, pure will, holy will, life, and the power of desire. In the course of the analysis a relation is brought to light in which these foregoing kinds of will incline towards moral worth. This in turn allows a discussion about differences between good and pure will as well as between moral possibility and moral necessity. Beside this, the article applies a typology (formulated in advance) of Kant's will-concept to the manifold definitions of will simpliciter that one finds in Kant's writings. This implementation shows that in the Kantian philosophy it is hard to ascribe a clear cut meaning to the concept of will as such and that one is rather advised to conceive of it always in terms of its modalities (enumerated above).

Key words: history of philosophy, freedom, will, free will, Willkür, libertas indifferentiae, Kant, Allison, Pantheism controversy. 
